\title{
Når tavshed brydes af vold mod romaer
}

\section{Martin Ehl}

\section{Hykleri og tavshed giver ekstremister for meget rum i debatten om et reelt eksisterende problem med romaer i Centraleuropa, mener tjekkisk redaktør}

Under en nylig debat om et opslagsværk om centraleuropæiske politiske teorier, som nu er under udarbejdelse, havde jeg et stort problem med at overbevise polske venner om vigtigheden af, at have temaet om romaer med. De forstod, at det er et nøglebegreb for Ungarn og Slovakiet $\mathrm{og}$ måske selv for Tjekkiet, men hvorfor for Polen?

Omkring en uge efter var det kun en hurtig reaktion fra polsk politi, som forhindrede lynchning af en romafamilie i en by i det østlige Polen. Og nu har vi i Bratislava en sag, som stinker af racisme, med mord på en romafamilie.

Det er ikke nødvendigt at overbevise slovakker, ungarere og tjekker om, at der eksisterer et problem med romaminoriteter. Tjekkiet har mere end 300 områder, der hovedsagelig er beboet af romaer, som kal- des 'socialt udelukkede', og den eneste opskrift på at ændre situationen, der har fået storstilet medieopmærksomhed, var forsøg fra Jiri Cunek, borgmester i Vsetin, på at udvise en gruppe romafamilier fra byen. (Hyldet af offentlig opbakning vandt Cunek et senatsvalg og blev siden formand for det Kristdemokratiske Parti).

\section{Ungarsk sendrægtighed}

Ungarsk politi har været langsomt til at efterforske mord på romaer i de seneste år, herunder mordene $\mathrm{i}$ februar 2009, hvor en romafamilies hus blev sat $i$ brand og en mand og hans lille søn, der flygtede, skudt og dræbt.

De fire mistænkte, der i løbet af to år har angrebet ni romaområder og dræbt seks romaer under affyring af 
i alt 78 skudsalver, blev første anklaget i sidste måned (august 2010. red.).

Slovakisk politi indrømmede først sent og modstræbende mandag (31. aug. red.), at ofrene for et skyderi i hovedstaden Bratislava var romaer. Politiet frygtede med rette reaktioner fra enten flertallet eller mindretallet i det slovakiske samfund. Skiftende slovakiske regeringer har forsøgt på den ene eller anden måde at løse situationen med romaminoriteter, der anslås at udgøre ti procent af befolkningen, og som er en voksende minoritet. Og som i Ungarn og Tjekkiet er der ikke dukket nogen magisk formel op.

Den mest lovende angrebsvinkel blev diskuteret for få måneder siden af Ludovít Galbavy, den slovakiske regerings ansvarlige for romasamfund. I et interview med mit tjekkiske dagblad, Hospodarske noviny, talte han om at bruge europæiske fondsmidler til bestræbelser for at for romabørn i skole og sikre, at romaer boede i kvarterer med arbejdspladser, elektricitet, vand og anstændige boligforhold.

\section{Huse eller deportation}

Det er klart, at penge kan bruges til at bygge huse (i det slovakiske tilfælde) eller til at sende mennesker væk (de seneste deportationer fra Frankrig). Men det er meget vanskeligere at ændre mentaliteten hos både flertallet og mindretallet.
Mange flere psykologiske mure er blevet rejst end dem i den tjekkiske by Usti nad Labem, der engang adskilte overvejende romakvarterer fra de nærliggende hvide kvarterer, eller dem i de slovakiske byer Michalovce og Ostrovany, der tjente samme formål.

\section{Racisme og frygt}

På den ene side eksisterer slet skjult mishag (racisme) blandet med frygt (for kriminalitet). På den anden side forskellige kulturer og mentalitet, frygt, mistillid ("Vi taler kun med udenlandske tv-hold", som en tjekkisk tv-journalist for nylig hørte i en romalandsby) og vanen med at kræve statslige almisser, som man blev vænnet til under socialismen.

Situationen er drevet så vidt, at selv om skyderiet i Bratislava i realiteten ikke var drevet af racisme, kan ekstremister på begge sider bruge det til at promovere deres formål og yderligere eskalere en social, sikkerhedsmæssig og politisk tidsindstillet bombe, som er forbundet med romaer.

Tag for eksempel det tredjestærkeste parti i Ungarn, Jobbik, hvis medlemmer organiserer paramilitære patruljer, hvor de værste spændinger eksisterer mellem flertallet og romaer, fordi ungarsk politi ofte anklages for, at de ikke er i stand til at beskytte 'respektable borgeres' liv og ejendom. Med sin åbent antiroma og skjulte antisemitiske retorik 


\section{BAGGRUND}

fik Jobbik næsten 20 procent af stemmerne ved parlamentsvalget i Ungarn (april 2010).

Hvad i alverden skal vi gøre, når vi ingen mirakelkur har oppe i ærmet?

Vi skal frem for alt holde op med lusket at bilde os ind, at der ikke er et romaproblem forbundet med skjult eller åben racisme. Det er bydende nødvendigt at tale åbent om romaproblemet $\mathrm{i}$ alle dets former og kalde tingene ved deres rette navn for at efterlade så lille et rum som muligt i debatten til ekstremister som folk fra Jobbik.

Martin Ehl er udenrigsredaktør ved det tjekkiske dagblad Hospodarske noviny.

(Oversat af Vibeke Sperling). 